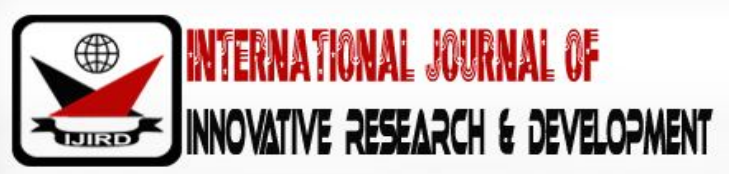

ISSN 2278 - 0211 (Online)

\section{Analysis on Some Causes and Consequences of North-South Migration of Fulani Pastoralists in Nigeria}

\author{
Hamman Jumba Ahmadu \\ Lecturer, Division of General Studies, University of Maiduguri, Nigeria
}

\begin{abstract}
:
The Nigerian state is witnessing the creep of Fulani pastoral migration from the North to the Southern part of Nigeria in search for better vegetation and palatable grasses to meet-up with their herd's pastoral needs. Paradoxically, this migratory trend was also necessitated by the increasing deficit of renewable resources in the northern region due to vulnerability to climate change related issues and general insecurity that is bedeviling the region in recent times. Critical to this migration is the continued sedentarization the Fulani pastoralists in the south which brings them into close contact with arable farmers and subsequent clashes that ensured between the new arriving Fulani pastoralists and the native in many parts of the southern states of Nigeria. However, the focus of this paper is to provide some analyses on the causes and consequences of North-south migration of Fulani pastoralists in Nigeria. In doing so the paper utilizes content analysis of the existing related literatures and unstructured focus group discussion with some group of arable farmers in the south and the migrant Fulani pastoralists. The paper argued that among the major causes of north-south migration of pastoralists is the glaring environmental complexities arising from desertification and acute water shortage, cattle rustling and general insecurity as well as the 'Boko Haram' insurgency has been the major catalyst exacerbating Fulani migration to the south with consequence of violent clashes in many parts of the southern communities. The paper concludes that in the absence of effective and efficient mechanisms that can mitigate the impact of climate related problems and general insecurity, Fulani pastoralists will obviously indulge in migration as a strategy for avoiding threats to their source of livelihood and survival.
\end{abstract}

Keywards: Migration, pastoralists, conflict, resources, security

\section{Introduction}

Nigeria is a colonial state contrived by the British in 1960. Since then the Nigeria has been confronted with several challenges of political instability; coups and counter-coups; ethno-religious intolerance; indigene-settler conflicts; youths restiveness in the Niger Delta; Boko Haram insurgency in the North-east; cattle rustling in the North-west; upsurge of ransomtargeted kidnapping and hostage taking in the south and central states; upsurge of farmer-herdsmen conflict particularly in southern Nigeria among others has continued to threaten the fragile peace and national unity as well as the cooperate existence of Nigeria. This development presupposes the weakening of the Nigerian state (Maiangwa and Ahmadu, 2010).

In recent critical years the Nigerian state is experiencing large migration of pastoral herdsmen from the north to southern parts of Nigeria as a result of climate related issues, cattle rustling and Boko Haram insurgency. The proliferation of pastoralists Migration trend has caused unprecedented conflicts between migrants' herdsmen and their new host farming communities in southern Nigeria. Migration is a cultural attribute to most Fulani pastoral herdsmen (Blench et al., 1998). Fulani pastoralists represent the largest migratory ethnic group in the world (Ducrotoy et al, 2018). The trend of migration among Fulani herdsmen started since the beginning of the twentieth century (Blench. 2003). Migration among the most vulnerable pastoral herdsmen in Nigeria is predicated on several factors prominent among them is the environmental changes and variability as well as lack of an effective alternative mitigating strategy needed to support adaptation to these environmental changes and variability (Adger et al, 2009; Sayne, 2011). However, push and pull factors also play significant role in influencing pastoral migration (Akinyemi, 2016). Some of these push factors in Northern Nigeria for instance, includes climatic changes, cattle rustling and the recent Boko Haram insurgency in north-east which influenced and increases the magnitude of pastoral migration to southern Nigeria. Similarly, availability of rich vegetation and pasture palatable to cattle, peaceful environment also serves as some of the pull factors in the north-south pastoral migration. Akinyemi, (2016) also explains that, some areas of south-west forest loops southwards close to the coastal areas of Benin and the republic of Togo, thus creating a relatively open land conducive and congenial for cattle grazing. From the available literature two patterns of pastoral migration are often discernible in Northern part of Nigerian pastoral corridor. First, is the transitory migration, and 
second, is the sedentary movement or relocation. Transitory migration refers to all year-round cycle of pastoral migration due to variability and climatic changes. While sedentary migration is a more permanent form of migration that can be short or long-term, temporary or permanent settlement (see Kratli 2008; Azuwike and Enwerem, 2010; Akinyemi, 2016).

The growing literature on climate-change-induced conflicts especially the Toronto group under Thomas Homer-Dixon mostly paid credence to the extant degradation of the ecosystem in the West African Sahel including Northern Nigeria precipitated by acute desertification, drought, depletion of pasture and other ecological problems as antecedents for several violent conflictsin the region. Vulnerable people like pastoralist are among the worst hit by the ecological problems which compelled them to move to southern states in order to find greener pasture for their herds as a panacea. Eventually that brings them into close contact with farmers and with attendant consequences of conflict over crop damage (Onuoha, 2011; Odoh and Chilaka, 2012; Akinyemi, 2016).The pattern of migration has increasingly brought them into unfriendly contacts with previously unfamiliar cultures, environment productive systems, and peoples (Akinyemi, 2016). Some researchers have earlier noted that more than half of vulnerable northern states like Bauchi, Kebbi, Sokoto, Jigawa, Kano, Borno, Gombe, Kaduna, Katsina, Yobe, and Zamfara states could turn desert or semi-desert in the $21^{\text {st }}$ century, because desertification in theSahel is fast creeping southward at a speed of 1,400 square miles annually affecting most villages (Odoh and Chilaka, 2012). This phenomenon has gradually compelled pastoralists to relocate to southern Nigeria as an alternative means of feeding their herds.

Beside vulnerability to climatic changes, the paper contends that theover one decade of Boko Haram insurgency has forced north-south migration of pastoralists worse than the impact of climate change. Some parts of the northeast became a no-go-area for pastoralists and other resource users. For the fear of becoming victims of Boko Haram violent activities, herdsmen were left with no option than migration to safer areas in southern Nigeria. However, the consequences of these increasing north-south migration are the upsurge of frictions, misunderstanding and conflicts between the host native arable farmers and the large number of migrants Fulani herdsmen from the North. This resulted into killings, destruction of lives and properties, Kidnappings, arson, rape among others.This development has continued to unleash threats to peace and unity of the Nigerian state. Discussion for this paper isfocused onfirst; examining the causes of north-south migration of herdsmen, secondly; explore the consequences of north-south migration of herdsmen and third, discuss its implications on peace and national unity.

\section{The Nature and Dynamics of Fulani Pastoral Migration}

The Nigerian pastoralists are comprised of various ethnic groups such as Fulbe or Fulani, Kanuri related groups,Shuwa-Arab among others. The Shuwa-Arabs and Kanuri related groups such as Koyam, Kenembu, Buduma, Bodawi, Manga, Uled Sulaiman among others confined themselves within the Lake Chad region. There are about 120 million pastoralists worldwide, 50 million in Sub-Saharan Africa and they constitute 12 percent of rural populace (Rass, 2006). They are found in more than twenty Countries (Fabusoro and Oyegbami, 2009). The Fulani are the largest pastoralist group in the world and they constitute about 95 per cent of the nomadic pastoralists in Nigeria with estimated population of 15.3 million (Majekodunmi, et al 2014).Fulani account for 4\% of the national population of Nigeria (World Atlas 2017 cited Ducrotoy, et al 2018). Across ages Fulanis are well known for deriving their livelihood and survival through mobile cattle rearing as a key strategy for survival. Their enormous contributions to Nigeria's agricultural food security and local food chain cannot be underscored. The Fulanis produce 90 percent of Nigeria's livestock population which accounts for one-third of agricultural GDP and 32 percent of the nation's GDP (Fabusoro and Oyegbami, 2009).According to Nzeh (2015) "Nigeria's livestock production sub-sector account for about 25\% of Central and Western Africa's entire livestock holding. This figure makes Nigeriathe leading producer of livestock in the sub-region with an estimated over 16 million herds of cattle ahead of Niger Republic's 8.7 million, Mali's 8.2 million, and Chad's 7 million herds. The sector in Nigeria also provides employment for a significant number of herders in the country." Unfortunately, despite their huge contributions to the economy of Nigeria, modern civilization has done little to their livelihood.

Pastoral mobility increases when climatic condition deteriorates under conditions of drought, desertification among others. Availability of pasture and otherwise determines their degree of mobility. However, there three groups of pastoralists in Northern Nigeria. First is the nomadic Fulani pastoral group such as Udawa, Mbororo among others whose mobility or migration pattern is determine by opportunity of resources or otherwise. The second group is the Trans- humane Fulani pastoral groups comprised of the Tareq, Uled Sulaiman among others have planned mobility or migratory routes on seasonal basis. The third group includes Koyam, Kanumbu, Shuwa-Arab, Fulbe Fombina among others who are agro-pastoralists sedentarized within the Lake Chad Basin. They simultaneously engaged in both livestock rearing and farming as sources of their livelihood and survival. Annual north-south pastoral migration becomes excessive from February to June when most of the wetland areas in the north have dried-up and hotter. When water borrow-pits and ponds has receded, rainy season vegetation and pasture has finished, crop residues from cultivated farmlands have been exhausted, ultimate north-south migration becomes the mitigating strategy of coping with the deficit in pasture.Paradoxically, between Julys to December when rainy season vegetation begins to appear, hence northward migration commences. However, central to the dynamics of Fulani pastoral migration trend is the availability and otherwise of land, pasture, water and security. Insecurity exacerbates pastoral migration as the case of Boko Haram insurgency in the northeast and cattle rustling in the northwest which compelled unusual pastoral migration. 


\section{Theoretical Framework}

The post-cold war period particularly the last two decades witnessed the evolution and emergence of eco-violence theory as a model for establishingthe links between climates related issues and human security especially in developing countries (Klare, 2000). The global concern for environmental-security and its implications particularly in developing nations triggered the zeal for academic researches. Few among these research publications are (Kaplan, 1994; Homer-Dixon, 1994, 1998; Karl, 2006). In an effort to justify the causal link between resource scarcity and violence, some team of researchers, first is the Toronto Group' from University of Toronto led by Thomas Homer-Dixon. The second was 'the Environment and Conflict Project' from the Swiss Federal Institute of Technology in Zurich and the Swiss Peace Foundation in Bern (Hagmann, 2005 cited in Akinyemi, 2016). Researches engaged by both 'Toronto' and Zurich group produced the Theory of Eco-Violence Model for understanding the nexus on how environmental scarcities contributes to breeding conflicts in developing nations (Percival and Homer-Dixon, 1998).

Central to eco-violence theory is the inter-connection between environmental changes and resource scarcity as responsible for competition and contestation over access to shrinking resources (Baechler, 1999; Karl, 2006; Homer-Dixon, 1999). They went further in concurrence with Malthusian theories that population growth brakes the 'shrinking resource pie' into smaller portion and disproportionate to the people who share from the same common resource pool (Isiugo and Obioha, 2015). Critical to the issue of resource scarcities is its influences on migration of people. For instance, pastoralist's migration is more often precipitated by scarcity of renewable resources in one place and its availability in another place as well as general insecurity like the case of Boko Haram insurgency in Northeastern Nigeria. The hitherto seasonal and temporary north-south migration of pastoralists from the Sahel is gradually becoming a permanent form of migration due to environmental and general insecurity in Northern Nigeria (Azuwike and Enwerem, 2010). However, resource scarcity induced migration of pastoral communities is not a new phenomenon but their continued sedentarization in south has consequently led to several violent conflicts with native farmers.

\section{Causes of North-South Migration of Herdsmen}

Several factors are responsible for the extant creeping north-south migration of herdsmen in Nigeria. Some of the major factors include: 1) Desertification, land depletion, resource decline due toclimatic changes and the quest for greener and palatable pasture 2) Cattle rustling, raids, and general insecurity 3) Boko Haram insurgency among others.

Desertification, land depletion, resource decline due to climatic changes and the quest for greener and palatable pasture: Intergovernmental Panel on Climate Change (IPCC) defined climate change as "any change in climate over time, whether due to natural variability, or as a result of human activity" (IPCC, 2007). The entire Sahel region including northern Nigeria has been facing acute desertification and land depletion due to relentless tree felling for firewood, bush burning among others. As a result, vulnerability and loss of sources of livelihood becomes severe among pastoralists and arable farmers with less or no mitigating strategy at their disposal other than migration. In trying to link climate related issues and pastoral migration, several researches on some specific case studies argued that, strenuous struggles and competition over access to and control over natural resources arising from its decrease in quality and quantity; increase in the population of herds; weak political institutions among others are responsible for climate related pastoral migration as well as the attendant tension and conflicts (see Galtung, 1982; Brundtland et al, 1987; Opschoor, 1989; Brock, 1991; Gleick, 1993; Homer-Dixon, 1991, 1994, 1999; Shetima and Tar, 2008; Akinyemi, 2016). According to Ahmadu and Yusof, (2010) tensions over claims to shrinking natural resources are mostly attributed to declining sources of livelihood and survival. However, the riparian states that share the Lake Chad, (Chad, Niger, Cameroun and Nigeria) in West and Central Africa are still grappling with pastoralist migration induced by deterioration of resources such as land, water, fodder and among others arising from increase in the number of users, receding lake water, desertification and other climatic changes that bedeviled the region since 1980s. For instance, the Lake Chad is among the Africa's largest inland lake providing livelihood support to more than 20 million people including herdsmen residing in about 30 shore-line communities in the four riparian states of Chad, Cameroun, Niger and Nigeria has been greatly affected by climatic changes (Onuoha, 2011). The Lake has gradually receded and lost 90 percent of its original size since independence (Masari, 2006). From late 1960s to 1997 the lake has receded from 26,000 square kilometers to less than 1,500 square kilometers (Coe and Foley, 2001). It further receded to an area of just 532 square kilometers in 2014 (Masari, 2006). This development has aided the current creep of north-south migration of pastoralists as an alternative strategy to sustain their traditional source of livelihood and survival.

Cattle rustling, raids and general insecurity: - Northern Nigerian herdsmen have been grappling with the menace of cattle rustling, banditry, raids and general insecurity in several communities. Cattle rustling are not a new phenomenon among herders, perhaps what is probably recent isthe current proliferation and widespread upsurge of cattle rustling and other criminalities in its violent form among herdsmenconstitute not only a threat to national security but has obscured increased north-south migration of herdsmen.According to Ducrotoy, et al (2018) Pastoralists, by virtue of their mobility, can flee insecurity in more volatile areas to go to locations wherepolitical tension and violence are less rife. Unlike the sedentary agriculturalists, who have to lose their land when they relocate. Most states in northern Nigeria are overtly or covertly affected by the menace of cattle rustling (Olaniyan and Yahaya, 2016) Approximately 7,000 cattle were rustled from commercial livestock farms and traditional herders in Northern Nigeria between October, 2013 and March, 2013 as reported by Kaduna branch Miyetti Allah Cattle Breeders Association of Nigeria [MACBAN] (Bashir, 2014 cited in Olaniyan and Yahaya 
2016). In Kano and Katsina axis, few months after the formation of joint security task force against cattle rustling more than 30,000 cattle was recovered from rustlers during the operation (Tauna, 2016cited in Olaniyan and Yahaya, 2016). The same thing in Jos Plateau state the special security task force set-up in response to several security challenges in the state reported that within a period of six months 160 attacks by gunmen led to the recovery of 2,501 cows from rustlers (Olaniyan and Yahaya, 2016).This atrocity goes beyond rustling because in most cases they maim and kill their victims, rape their women or kidnapped them before dispossessing them of their cattle (Akowe and Kayode, 2014; Adeniyi, 2015; Olaniyan and Yahaya, 2016).

Boko Haram insurgency - Boko Haram is officially known as (Jama'atul Ahlul Sunah lil Da'awati Wal Jihad). Nearly one decade of Boko Haram relentless violence and hostilities in the North-east has caused several damages to lives and properties as well as displacement of over two million people a reported by National Emergency Management Agency (NEMA). Herdsmen by virtue of their rural livelihood become easy soft target in the hands of Boko Haram dissidents. Their cattle arebeing rustled on daily basis as a source of fund to Boko Haram insurgents as confirmed by Governor Kashim Shettima of Borno State. In his words:

"Our security agencies have reasonably established that most of the cattle being traded at the markets [in Borno State] were the direct proceeds of cattle-rustling perpetrated by insurgents [and] were sold at prohibitive costs to unsuspecting customers through some unscrupulous middlemen who use underhand ploy[s] to deliberately disguise the transactions as legitimate. The money realized from such transaction[s] would then be channeled to fund their deadly activities"(Ogbeche 2016 cited in Olaniyan and Yahaya, 2016 p.98).

It was against this reports Governor Kashim Shettima of Borno State impose a total closure of cattle market as well as ban on the sale and trade of dried meat and cattle to members of Butchers and Cattle Breeders Association of Nigeria Borno State branch (Ogbeche, 2016 cited in Olaniyan and Yahaya, 2016). The unrelenting rustling of cows by Boko Haram insurgent forced many pastoral communities to migrate to the south for security of their lives and that of their herds.

\section{Consequences of North-South Migration of Herdsmen}

Some of the major consequences of North-south migration of herdsmen are the frequent violent clashes between the migrants' herdsmen and their host communities in the south who are mostly indigenous arable farmers. In the last few years the upsurge of these violent clashes in southern Nigeria led to several destructions to lives and properties. In south-west for instance, On April 20, 2016, suspected Fulani herdsmen attacked about five communities in the Lagelu Local Government Area of Oyo State killing and injuring unspecified number of persons and several properties destroyed (Esho, 2016). Prior to Lagelu attack, on September 21, 2015 Fulani herdsmen attacked and kidnapped the former Minister of Finance and Secretary to the Federal Government Chief Olu Falae in his farm in Ondo state. The kidnappers suspected to be Fulani herdsmen demanded for a ransom and were paid \$5 Million (Five Million Naira) before releasing him (Premium Times, 2015; Oluwole, 2015; Nathaniel, 2015).On May 20, 2016, Fulani herdsmen carried out an attack in Oke Ako in Ikole Local Government Area of Ekiti state and killed two persons while six others were seriously wounded (Adeoye \& Alagbe, 2016). Theincessant violent activities of Fulani herdsmen in Ekiti State precipitated the State Governor to initiate a bill which was subsequently signed into law in order to regulate the activities of these herdsmen in the state.

In South-eastern Nigeria the consequences of herdsmen north-south migration became common and widespread in the region leading to frequent violent clashes. For example, On August 25, 2016 Fulani herdsmen attacked Ndiagu Attakawu Akegbe Ugwu Community in Nkanu West Local Government of Enugu state killing a Seminarian of the Catholic Church while four others were seriously wounded (Nathaniel, 2016; Vanguard, 2016).In 2015 some communities in three Local Government councils in Abia state (Uzuakoli in Bende Local Government Area, Ebem and Akanu in Ohafia and Umuchieze in Umunneochi) there have been cases of deadly clashes between rural farmers and these cattle breeders (Nwopara \& Okoli, 2015). The same thing in Anambra State, 4 people lost their lives in Ayamelum and Awka North local government areas and farmlands destroyed due to violent activities of Fulani herdsmen (Ezeonwuka \& Igwe 2016). Farmers and villagers in Imo State have gory tales to tell. Emotions ran high and tension was electric recently as scores of angry youths of Irete community in the state blocked the ever-busy Owerri - Onitsha dual carriageway to protest the damnable activities of Fulani herdsmen in their community (Nwopara \& Okoli, 2015). In Ebonyi State, people are not comfortable with the activities of Fulani herdsmen who tend to become very violent at "slightest provocation". The women came out in the streets of Ishiagu recently protesting against destruction of their crops by the Fulani herdsmen.

South-south Nigeria is also not left out, on December 22, 2016 Fulani herdsmen attacked Agbarha kingdom in Delta and kidnapped the traditional ruler Orhifi Enemor II. The kidnappers (Fulani herdsmen) demanded for \#50 Million (Fifty Million Naira) ransoms for his release. It was also the Fulani herdsmen that kidnapped and killed the traditional ruler of Ubulu Uku kingdom in Delta state Chief Edward Akaeze Ofulue III on January 5, 2016 (Jones, 2016; Amaize \& Ahon, 2016). On April 19, 2016 the entire Local Government Areas of Delta state brought economic activities of the state to a halt while protesting against the killing of 23 persons in the state by Fulani herdsmen. 59 persons were killed in Ugondo, Turan and Gabo Nenzev communities in Logo Local Government Area by Fulani herdsmen on June 20, 2016 (Agbedo, 2016). 


\section{Conclusion}

Pastoral migration is not a new phenomenon in Nigeria and the Sahel in general. What is probably worrisome is the creeping migration of Fulani pastoralists from the north to the south which was hitherto periodic and seasonal to sedentarization on permanent basis with consequences of violent clashes between the pastoralists and farmers. Fulani pastoralists often migrate southward in the absence of mechanism for mitigating environmental scarcities and general insecurity. This development generated a lot of concerns and questions on the efficacy of the current Nigerian federal system.In addition, the upsurge of violent conflict between the migrant pastoralists and the native farmers across the southern states raised some agitations and clamor for restructuring and establishment of state police in order to complement in curbing the increasing security challenges. However, government at all levels must develop policies and programs that can curb the menace of environmental scarcities and security concerns on sustainable basis to foster peace and reduce North-south migration in Nigeria.

\section{References}

i. Adeoye, G., \& Alagbe, J. (2016). B' Haram, Fulani herdsmen kill over 3,000 under Buhari. Retrieved from: http:/ / punchng.com/ b-haram-fulani-herdsmen-kill-3000-buhari/

ii. Adeniyi, Taiwo (2015), Why Incoming FCT Minister Must Act Fast onCattle Rustling, in: Daily Trust, 1 July, online: Retrieved from www.dailytrust.com.ng/ daily/ index.php/ city-news/ 58662-why-incoming-fct-administrationmustact-fast-on-cattle-rustling>

iii. Adger, W. N., et al. (2009) Are there social limits to adaptation to climate change? Climatic Change, 93, 3,335-354.

iv. Agbedo, O. (2016). Tracking endless Fulani herdsmen/farmers clashes. Retrieved from: http:/ / sunnewsonline.com/ tracking-endless-fulani-herdsmenfarmers-clashes/

v. Ahmadu, H.J. and Yusof, R. (2010) Resource Conflicts in Developing Countries: Reflections on Nigeria and Malaysia. Maiduguri Journal of Arts and Social Sciences, 8, 2, 215 - 224.

vi. Akinyemi, T. E. (2016) Climate Change, Migration and Resource Contestations: A case study of North-south Migration in Nigeria. Unpublished PhD Thesis. University of Kwazulu-Natal, Pietermaritzburg.

vii. Akowe, Tony, and Bodunrin Kayode (2014), Cattle Rustling: A NorthernNightmare, in: The Nation, 30 March, online: $<$ http:/ / thenationonlineng.net/ cattle-rustling-northern-nightmare>(30 August 2016).

viii. Amaize, E., \& Ahon, J. (2016). How Fulani herdsmen abducted, killed Delta monarch. Retrieved from: http:/ / www.vanguardngr.com/ 2016/ 01/ how-fulani-herdsmen-abducted- killed-delta-monarch/

ix. Azuwike, O. D. and Enwerem, E. (2010) Nigeria's Changing Environment and Pastoral Nomadism: Redistribution of Pains and Gains. Imo State University.Retrieved from:297 http:/ / www.diss.fuberlin.de/ docs/ servlets/ MCRFileNodeServlet/ FUDOCS_derivate.

x. Baechler, G. 1998. Why Environmental Transformation Causes Violence: A Synthesis. Environmental Change and Security Project Report, 4, 24-44.

xi. Blench, R. et al. (1998) Resource Conflict in Semi-Arid Africa: An Essay and Annotated Bibliography. ODI Research Study. Overseas Development Institute.

xii. Brock, L. (1991) Peace through parks: The environment on the peace research agenda. Journal of Peace Research, 28, 4, 407-423..

xiii. Brundtland, G. H. et al (1987) Our World Future. World Commission on Environment and Development. Oxford: Oxford University Press.

xiv. Coe, M.T. and Foleys, J.A. (2001) Human and Natural Impacts on Water Resources in the Hadeja-Nguru Wetlands, Nigeria. London Creen Working Paper No 13 IIED

xv. Ducrotoy, et al. (2018) Pattern of Passage into Protected areas: Drivers and Outcome of Fulani Immigration, Settlement and Integration into the Kachia Grazing Reserve, Northwest Nigeria. Pastoralism: Research Policy and Practice, 8, 1, 1 - 16.

xvi. Esho, J. I. (2016). Killer herdsmen and Nigeria's existence. Retrieved from: http:/ / www.punchngr.com/ fulani/ Killerherdsmen-and-Nigeria's-existence.html

xvii. Ezeonwuka, I. F., Igwe, A. U. (2016). Emerging Challenges in Nigeria's National Security in the Twenty-first Century: The Fulani Herdsmen Menace. Asian Journal of Multidisciplinary Studies, vol. 4, 5, 205 - $214 .$.

xviii. Fabusoro, E. and Oyegbami, A. (2009) Key Issues in Livelihood Security of Migrants Fulani Pastoralists: Evidence from South-west Nigeria. Journal of Humanities, Social Sciences and Creative Arts, 2, 1- 20 .

xix. Galtung, J. (1982) Environment, Development and Military activity: Towards Alternative Security Doctrines. Oslo: Norwegian University Press.

xx. Gleick, P. H. (1993) Water in crisis: A Guide to the World's Fresh Water Resource. (Ed) Environment and Development. Oxford: Oxford University Press.

xxi. Homer-Dixon, T. (1991) On the Threshold: Environmental as Causes of Acute Conflict. International Security,16, 2, 76116. 
xxii. Homer-Dixon, T. F. (1994) Environmental Scarcities and Violent Conflict: Evidence from Cases. International Security, 19, 5-40.

xxiii. Homer-Dixon, T. (1999) Environment Scarcity and Violence. Princeton: Princeton University Press.

xxiv. IPCC (2007) Climate change 2007: impacts, adaptation and vulnerability. Working Group II contribution to the Fourth Assessment Report of the IPCC Intergovernmental Panel on Climate Change. Geneva, IPCC Secretariat.

xxv. Isiugo, P. N. and Obioha, E. E. 2015. Understanding Theoretical Underpinning of Wildlife Resource Based Conflict in Oban Hills, Nigeria, Kamla-Raj Journal of Hum Ecology, 49 1-2, 153-161.

xxvi. Jones, C. (2016). Herdsmen attack Delta community and abduct the king. Retrieved from: https:/ / www.naij.com/ 1078841-herdsmen-attack-delta-community-abduct-king.html?

xxvii. Kaplan, R. D. 1994, The Coming Anarchy, The Atlantic Monthly, 2, 2, 44-76.

xxviii. Klare, M. T. 2000. Resource Competition and World Politics in the Twentieth-First Century. Current History, 99 641, 403-415.

xxix. Krätli, S. (2008) Cattle breeding, complexity and mobility in a structurally unpredictable environment: the WoDaaBe herders of Niger. Nomadic Peoples, 12, 1, 11-41.

xxx. Majekodunmi, et al. (2014) Pastoral livelihoods of the Fulani on the Jos Plateau of Nigeria. Pastoralism: Research, Policy and Practice, 4,.20, 1-16.

xxxi. Masari, A. B. (2006) Keynote Address delivered at the International Workshop on Current Challenges and Future Prospects of Lake Chad Basin, Organized by the Regional Parliamentary Committee on Lake Chad Basin, held at Transcorp Hilton Hotel, Abuja. 27-28 October 2006. Unpublished Manuscripts.

xxxii. Maiangwa, J. S. and H. J. Ahmadu, (2010) Insights of Nigeria's Political Instability since Independence: Alternative Proposal for stability. Nigerian Social Science Review 2, 1, 1-16

xxxiii. Nathaniel, S. (2015). Chief Olu Falae Kidnapped In Ondo State. Retrieved from: https:// www.naij.com/557966breaking-gunmen-kidnap-former-sgf.html

xxxiv. Nwopara, C. Okoli, A. (2015 October, 3). Menace of Fulani Herdsmen: Tales and Woes from the East. Vanguard Newspaper.

xxxv. Nzeh, E. (2015) The Effects of Migration by Nomadic Farmers in the Livelihoods of Rural Crop Farmers in Enugu State, Nigeria. Global Journal of Science Frontier Research: D Agriculture and Veterinary,15, 3, 20-28.

xxxvi. Odoh, S. I., and Chilaka, . F. C. (2012) Climate Change and Conflict in Nigeria: A Theoretical and Empirical Examination of the Worsening Incidence of Conflict between Fulani Herdsmen and Farmers in Northern Nigeria. Oman Chapter of Arabian Journal of Business and Management Review,2, 1, 110-124.

xxxvii. Okunola, R.A and Ikuomola, A. D (2010) The socio-economic implication of climatic change, desert encroachment and communal conflicts in Northern Nigeria. American Journal of Social and Management Sciences, vol. 1 no 2 pp. 88-101.

xxxviii. Olaniyan and Yahaya (2016) Cows, Bandits and Violent Conflicts: Understanding Cattle Rustling in Nigeria. African Spectrum, 57, 3, 93 - 105.

xxxix. Oluwole, J. (2015) How I was abducted, tortured, released-Olu Falae. Retrieved from: http:/ / www.premiumtimesng.com/ news/ headlines/ 190728-how-i-was-abducted- tortured-released-olu-falae.html

xl. Onuoha, F. C. (2011) Environmental Degradation, Livelihood and Conflict: A Focus on the Implication of the Diminishing Water Resources of Lake Chad for North-Eastern Nigeria. from:http:/ / mercury.ethz.ch/ serviceengine/ files/ ISN/ 98432ichaptersectionsingledocument/ 08af83f8pdf

xli. Opschoor, J. (1989) North-South Trade, Resources Degradation and Economic Security. Bulleting of Peace Proposals 20, 2, 135-141.

xlii. Premium Times (2015). How we shared N5million ransom - Olu Falae's suspected kidnappers. Retrieved from: http:/ / www.premiumtimesng.com/ news/ more-news/ 191550-how-weshared-n5million-ransom-olu-falaessuspected-kidnappers.html

xliii. Rass, N. (2006) Policies and Strategies to address the Vulnerability of Pastoralists in Sub-Saharan Africa. Rome: Propoor Livestock Initiative. FAO

xliv. Sayne, A. (2012) Rethinking Nigeria's Indigene-Settler Conflicts, United States Institute of Peace. Available at: http:/ / www.usip.org/ sites/ default/ files/ SR311.pdf.

xlv. Shettima, A. G. and Tar, U. (2008) 'Farmer-pastoralist Conflict in West Africa: Exploring the Causes and Consequences. Journal of Information, Society and Justice, 1, 2, 63-184.

xlvi. Vanguard. (2016). Enugu herdsmen attack: Police arrest suspected mastermind. Retrieved from http:/ / www.vanguardngr.com/ 2016/ 08/ enugu-herdsmen-attack-police-arrest-suspected- mastermind/ 